\title{
Contour Map of the Waves
}

\section{by Kiyosht Kasamatsu}

We have decided to draw a contour map of the waves on the other from National Disaster Prevention Scientific and Technical Center. We photographed the waves in following two ways from planes simultaneously, with the cameras equipped with synchronous shutter mechanism.

1. Successive stereophotographs are taken, so that the sea shore and oil towers in the sea can be imaged in a stereomodel and some reference points can be furnished for the facilities of the absolute orientations and the plotting works.

2. Under a basis of stereoscopic Observation, successive stereophotographs are taken so that a datum plane of $0^{\mathrm{m}}$ can be found by the numerical method and then the wave map can be plotted.

まえがき 同時撮影法により垂直空中写真を撮影し 実体写真測量を行う試みは, 1955年アメリカで行われ だ)ととがあるが，今回国立防災科学技術センターに 㧈いて精密な波浪等高線図作成が企画せられ，同セン ターの岩田憲幸氏より下記の指示を載き国際航業株式 会社に招いて実施し，一応の成果を得たので報告す る。

a 同時撮影装置を有する飛行機 2 機によりカラー フィルムを用い縮尺 $1 / 7000$ で撮影する。

b 撮影範囲は新潟県大潟県海岸及び同沖合 $1.2 \mathrm{~km}$ にある帝国石油株式会社給油タワーを中心とする 範囲

c 図化はステレオプラニグラフC 8 を用い, 縮尺 $1 / 1000$, 主曲線 $20 \mathrm{~cm}$ とする。

\section{1. 撮影}

撮影記録の拔萃は次の通りである。

昭和40年 4 月 12 日

離陸 $10^{\mathrm{h}} 40^{\prime}$ 撮影開始 $11^{\mathrm{h}} 40^{\prime}$

着陸 $12^{\mathrm{h}} 40^{\prime} \quad$ 終了 $12^{\mathrm{h}} \quad 1^{\prime}$

撮影縮尺 第 1 回 $1 / 7000$

第 2 回 $1 / 5000$

基地飛行場 新潟

カメラ $\mathrm{RMK}{ }^{15} / 23$

フィルム＼cjkstart富士カラー

* 国際航業業株式会社

写真测量 Vol. 4 No. 4 1965年

$$
\begin{aligned}
& \text { フィルター なし } \\
& \text { シャッター } 1 / 250 \text { 絞り } 5.6
\end{aligned}
$$

高層雲あり

標定図は第 1 図の通りである。

以上の通りて概ね予定通りの撮影が行われた。カラ ーフィルムを用いたのは，測定に当って青い海面に対 しステレオプラニグラフC 8 の測標は赤色光を用いる ことが出来るので, 対照が容易で観測がやり易い効果 を期待したものである。乙れは黒白ポジフィルムの場 合と比較して観測した結果によるととれに従事したプ ラニグラフのオペレーターは皆カラーの容易さを認め た。但し，測標が黒色或は白色光のみの図化機ではそ れ程の效果はないか专知れない。

波の撮影は太陽の反射光の状態によって写真のディ テールが得られる。又撮影高度によっても異るので, 江の島附近で撮影訓練を行ったときの結果から見う と，正午前後の太陽の反射の多い部分のみが実体観が 得られた。たまたま後 3 時30分頃撮影したものは殆 んど波形がうつらないばかりでなく，防波堤や岩礁の 内側では海面を通して海底が撮影されてしまった。

これ等のととから撮影時期は正午前后を選定すると ととした。

又ステレオ写真は，写真の調子が全く等しくなる様 に撮影されなければならないが，陸上と異り非常にむ つかかいのである。

ある時間に撮影された写真上の明，暗部はその前後 の連続写真に扔いては，どのコースも同じ関係に出て 


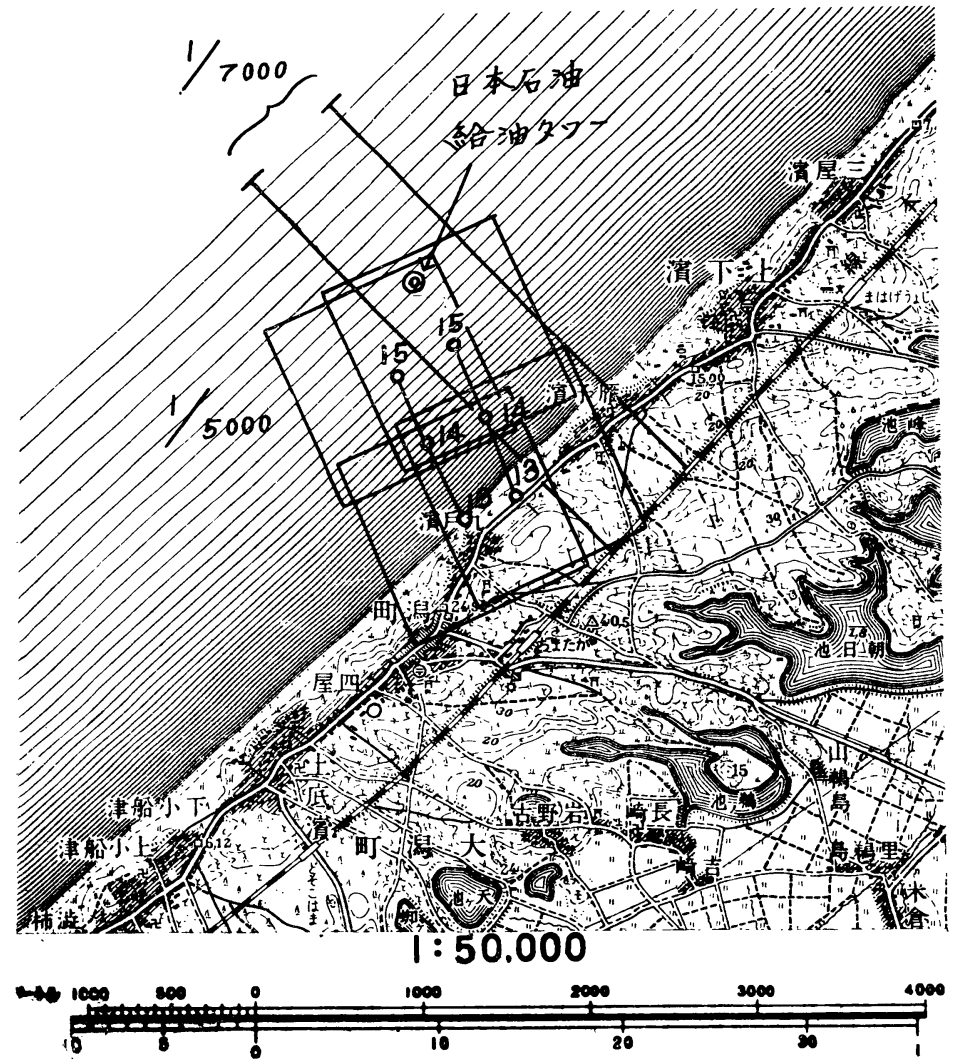

第 1 図 撮影写真標定図

Fig. 1, On tre map. photographic project is illustrated.
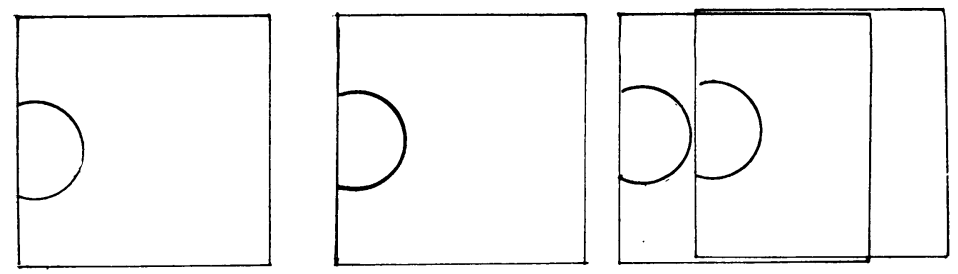

第 2 図A ステレオに困難な写真の例
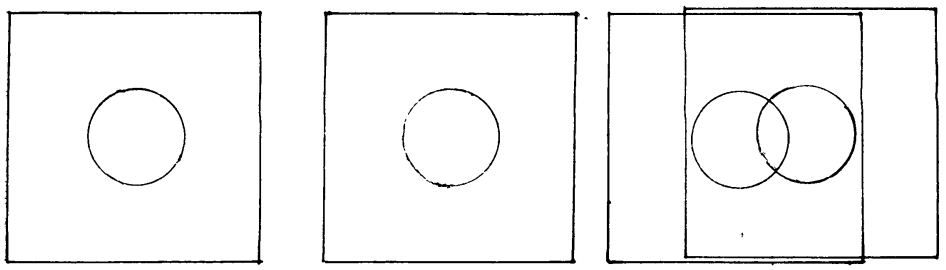

第 2 図B 太陽反射光の良い例
Fig. 2B, A Desirable example on reflected sun light.

くる。従って，これを実体視するの に都合のよいようにするには写真の 中央附近飞写真の明部が来るように 計画する必要がある。第 2 図に心A にステレオに困難な写真の例を，B に適当な例在示した。

B図のようなステレオ写真学得る ためには，太陽の照射方向と撮影方 向とを一致すればよく，本撮影に打 いてもこれに留意して計画された が，気象の影響により子定通りの時 間に撮影することが出来ないととが あるので，時間による撮影計画をた てて抢くことが必要である。

動く波を撮影するには飛行 2 機に よる同時撮影装置が必要である。乙 れは国際航業株式会社の開発した装 置2) 用いたのであるが，同社研究 室長中村貢治氏の助力により，同室 研究員山上貢氏が完成したもので， 気象測定の目的を以て煙の同時撮影 を行った装置で，その当時より安定 度が增している。

この装置の性能は，概ね次のと拝 りであ今。

a 通達距離は 2 料

b 航空力カメラと連動している

c 音声によミ通信とカメラのシ

ヤッター作動こが容易に切澳え られる。

$\mathrm{d}$ 他の電波及び飛行機の内部の 妨害により機能悹低下し，或は 故障亨起すようなととがない绨 な雑音フィルター装置离持って いる。

e シャッター作動の同時性は

$1 / 50$ 秒以下であ岕。

航法こしては; 飛行機の進行方向 に対して平行して他の一機力榌ぶ方 法と，マスター一機に対し他の一機 が追随していく方法とがある。便宜 上前者を平行法, 後者を追随法とッ ると，

a コースの保持は追随法が容易である。

かしい。即ち完全に平行して飛ばないで前後する

b 雨者の撮影間隔の保持てついては, 平行法の方 と，ステレオ部分が少くなってしまう。 が容易な場合が多い。

c 平行法は完全なステレオ写真を得るととがむづ
今回は撮影区域が陸地に近く, 海上に明瞭な固定目 標物があったので，平行法を採用した。撮影結果の一 


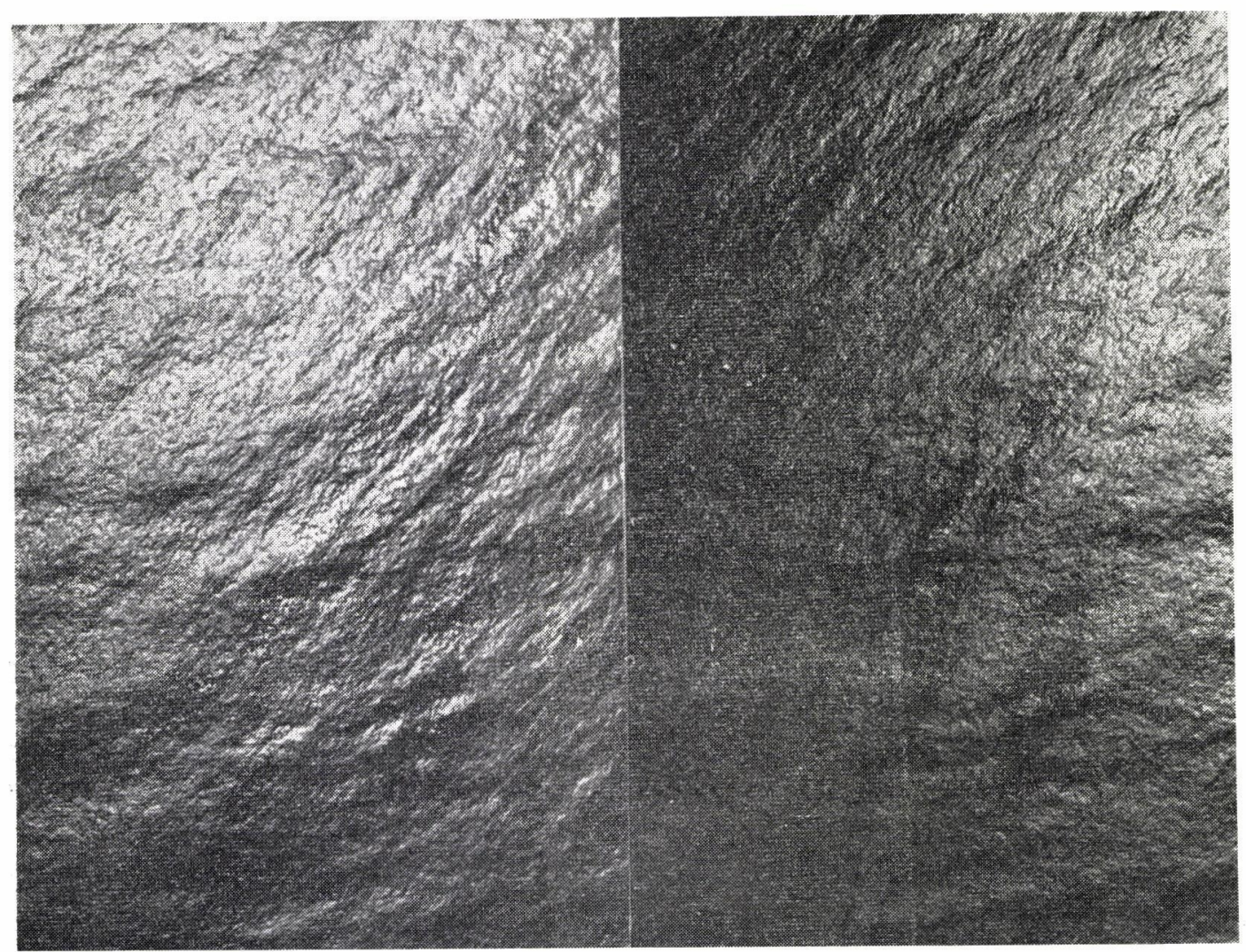

第 3 図 波浪ステレオ写真縮尺 $1 / 5,000$

Fig. 3, Stereogram of the waves on a seales of $1 / \bar{j}, 000$.

例は第 3 図の通りである。

\section{2. 測 定}

\section{2-1 準诮及び計画}

現地の海岸に扔いて写真に明瞭に刺針の出来る地点 を選定し，とこに基線を設定し海上の人工島を海上基 準点とし三角測量により関係位置を求めた。これによ り海岸と海上基準点とにより空中写真の絶対標定を行 い得るようにした。然しての方法によるか後述の方法 によるかは撮影された写真によって決定するとととし た。

撮影された写真の縮尺は計画通り $1 / 7000$ と1/5000の 二種類が得られたが，何れも海上基準点周辺の海面は 実体視が困写真の縮尺を求める以外は海上基準 点を使用する意味がないので, 写真の絶対標定には用 いないととにした。

\section{2-2 実施}

2.2.1. ステレオプラニグラフによる第一次概略絶 対標定

同時撮影による写真の重複部中第 4 図のように, 1 〜 2, 3〜 4 線走選定し, 1, 2, 3, 4 点には子小刺針
京行い標定のための点と した。 $1,2,3,4$ 点を標 高 $0 \mathrm{~m}$ と見做し第一次の 写真の絶対標定を行っ た。この選点は, スデレ オモデルの全部が実体視 出来るのではなく，60\% 程度であるから，これら

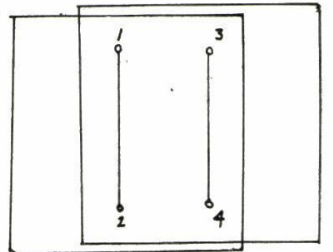

第 4 図 標定点

Fig. 4. Model points for orientation.
の点は実体視の出来る範甩の外周に置加る。

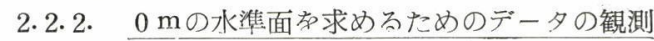
写真の縮尺は1/5000で行うとととした。これは海上 基準点を使用しない限りなるべく大縮尺の方が良いか

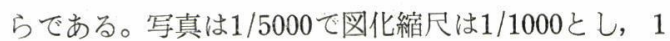
〜 2, 3〜 4 線を展開し各々の線上 $5 \mathrm{~mm}$ 間隔て高さ Zの測定空行い総数約 350 点のデータを得た。

\subsection{3. 水準面の計算方法}

真高 $\Delta Z i$ が得られた場合, 第 5 図のように $\Sigma \Delta Z=$ 0 になるような直線 0 は水準面であるとの仮設を設け た。次に，第一次絶対標定で測定した $5 \mathrm{~mm}$ 間隔の高 さは，概略面からの価 $2 i$ で，乙れに真の水準面に対 する修正量子を補正してはじめて真の標高 $\Delta Z i$ が得ら 


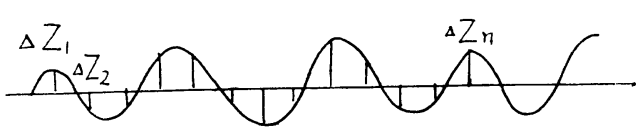

第 5 図 仮の水準面

Fig. 5. A temporary datum plane.

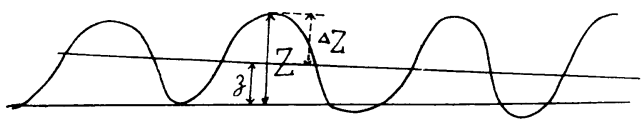

第 6 図 真の水準面

Fig. The true datum plane.

れる。これる図示すると第 6 図の通りである。

第 6 图の 0 直線は, 概略標定面に対し, 次の関係が

ある。 $a X+c=z$

$\boldsymbol{z}$ は下明であるからZ 老用い最小自乗法を用い，係 数 $a, c$ の最確值を永めれば, 任意の点に招いて $a X i+C=Z i$ によって計算された $z i$ 加ら $Z i-z i=$ $\Delta Z i$ を求めれば最初の仮設のように $\Delta \Delta Z=0$ になる。

即ちこの計算は次のように行なう。

$\left\{\begin{array}{l}a X_{1}+C=Z_{1} \\ a X_{2}-C=Z_{2} \\ \cdots \cdots \cdots \cdots \cdots \\ a X_{n}+C=Z_{n}\end{array}\right.$
これから次の正規方程式が得られる。

$\left\{\begin{array}{l}a[X X]+C[X]=[X Z] \\ a[X]+C n=[Z]\end{array}\right.$

$n$ は 170 以上となるので上式の計算は電子計算機に よって行った。

$3 \sim 4$ 線に打いても同樣の方法により $a, C$ を求め 同様に $a \times+C=z$ 在計算し， 3,4 点の $Z-z=\triangle Z$ (標高)を求めかくして絶対標定のための 4 点 $1 \sim 4$ を 点の標高を確定した。

\subsection{4. 写真の第 2 次絶対標定}

$1 \sim 4$ 定点中任意の 3 点を用い絶対標定を行ない, 他の一点の標高を読定し全く較差を認められなかった

これにより $1,2 ， 3 ， 4$ 点は一平面にあるととが 点検された。

\section{$2 \cdot 2 \cdot 5$. 等高線の描画}

$20 \mathrm{~cm}$ の等高線は相当むつかしく，実体視の容易な 部分から逐次外方に至るに従い精度が低下するので， 描画速度は極めて遅い。然し一般地形図と異り等高線 の総数が少いのとコンターのみであるから，一モデル の総時間はむしろ地形図の場合よりむ少い。

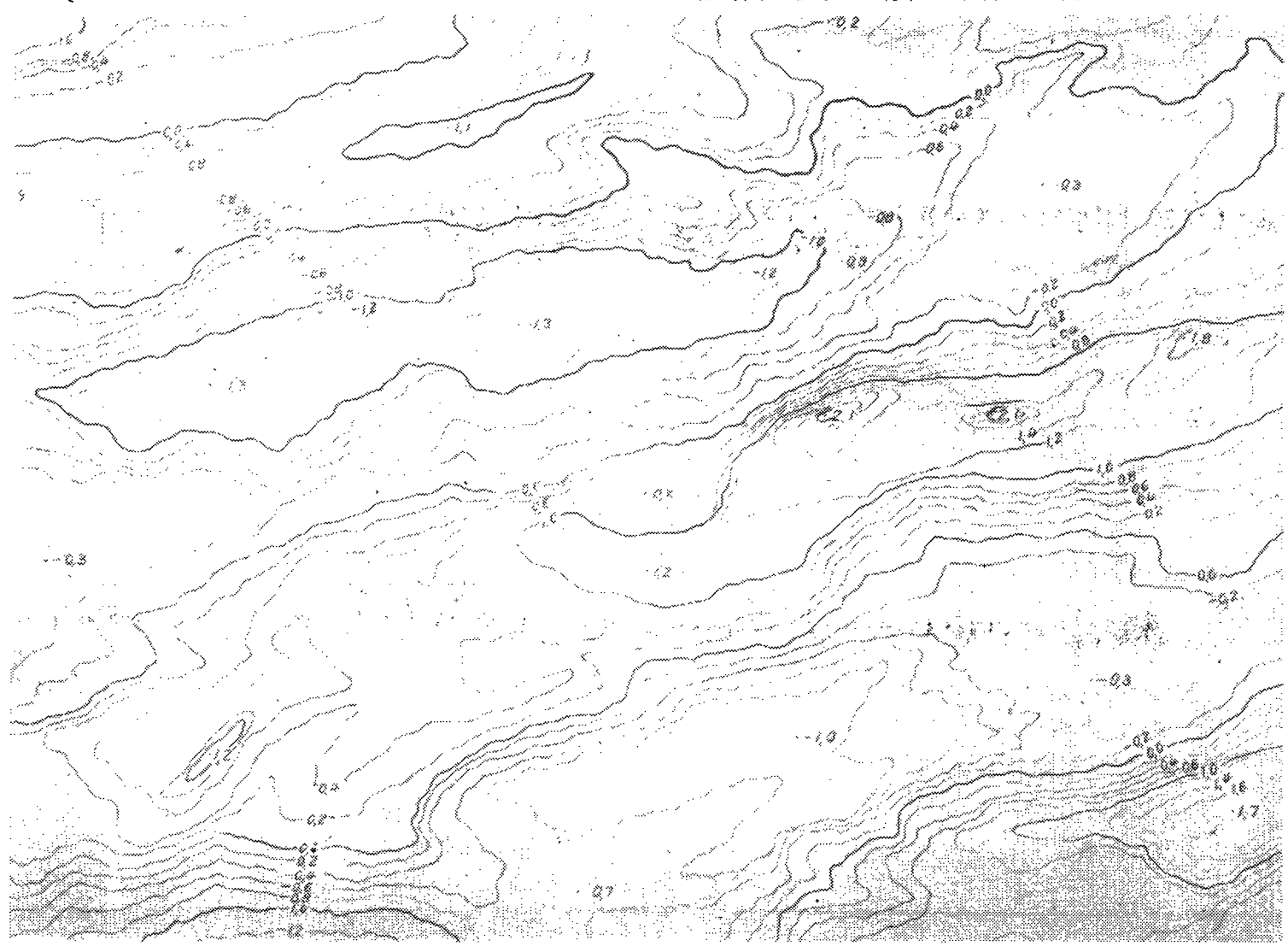

第 7 図 波浪等高線図（縮尺 $1 / 1000$ を $1 / 2$ 亿縮小，等高線間隔 $20 \mathrm{~cm}$.）

Fig. 7, A contour map on the waves, (Map on the scale $1 / 1000$ with contour interval $20 \mathrm{~cm}$. This copy is reducted to $1 / 2$ ) 
成果の一例は第 7 図の通りである。

\section{3. 実施結果より見た所見}

以上によって波浪の等高線図を空中写真加ら作るこ とが出来たが，今後しの様な等高線図を作るために所 見を述べると次の通りである。

\section{1. 撮影法}

ステレオ写真が同じコントラストで撮影されるため には追隋撮影法の方が有利である。平行法の場 合に は, 太陽光線と方向在一致するため計画撮影時間が変 更されると，撮影コースも変更しなければならない不 利がある。但し，撮影基線長の保持については，平行 法より因難を伴うと思われるので一応の訓練が必要と なる不利はある。

\section{2. 水準面を求めるための他の方法}

$a X+C=Z$ の式は直線式で $1 \sim 2,3 \sim 4$ 㕝別々に 計算したのであるが，下記の平面の式を用い一拠に計 算する方が良いではないかと思う。

$$
a X+b y+C=Z
$$

この式を用いた場合, 約 $10 \mathrm{~cm}$ 水準面が高くなった 結果が得られたが，この方が一般に良い様に思われる が，点検の資材が少いのて確固たる絬論は出すととが できない。

$$
a X+b X y+c=Z
$$

の式を適用すると $X Y$ の項があるために曲面とな り，例えば $1 ， 2 ， 3$ 点で絶対標定を行い, 第 4 点在 測定すれば較差が出る。これによって精度判定の資と することが出来るし，較差 $\triangle Z$ が微少であれば 2 と 4 に半量づつ配分し絶対標定を終了する。

\section{3. 本法の適用}

本方法は陸上基準点に何等関係なく実施出来ること
が最大の特焦で，如何なる場合にも水準面を求めるこ とが出来る。但し海岸の近くとか，或は特殊な場合に 本文中の $\sum \Delta Z=0$ (第 5 図) の面が平面にならない場 合は真值を表わさない。何れの場合に德用出来ないか は今後の課題であろう。

次に, 今回は海岸に近い為と, 海上基蕉点があった為 㝍真縮尺の決定は正確に行われたのであるが，比高の 公式 $d H=\frac{H}{b+d p} d p$ を考えて見ると, 求める $d H$ は，精々数米汅しか過ぎない。今回の場合定例にとる と， $H=750 \mathrm{~m}$ であるから $d p=0.5 \mathrm{~mm}$ として $d H=$ $\pm 5.3 \mathrm{~m}$ となり先ず最大の場合と考え, 上記公式から,

$$
\partial d H=\frac{d p}{b+d p} \partial H \text { の } \partial H \text { は } \partial d H=20 \mathrm{~cm} \text { とし }
$$

て計算すると $\partial H \fallingdotseq 28 \mathrm{~m}$ である。即ち, 求める $d H$ の 価が少いからHの測定もそれ程钽密を要しないことが わかる。従って，今後全く海岸より離れた海面に打い て行うときは, 最も近い海岸の撮影縮尺を求め, 測定 区域附近との高度差を修正すれば良いと思う。

若し特別海岸より離隔した場合には，スタトスコー プ（高度差記録計）装備した航空カメラを用いれば 万全であると思う。

あとがき 本研究に際し, 主として図化に関して田 辺晴正氏，計算について田浦秀春氏，石井和夫氏，並 びに測定及び撮影に協力された方々に謝意を表する次 第である。

\section{参考交献}

(1) Wilber Marks, FClaude Rome; “Aerial Stereo. photography and Ocean Waves" Photogram" metric Engineering XXI-1, 1955, PP107-110

（2）笠松 清外 “発煙の空中同時撮影による気象観

\begin{tabular}{|c|c|c|c|}
\hline ページ & 行 & 正 & 誤 \\
\hline 9 & 24 & $n$ 次式 & 次式 \\
\hline II & 10 & 坐標系を $\pi$ だけ & 座標系をだけ \\
\hline B & 2 & $\triangle \varphi_{1}, \triangle \varphi_{2}$ & $\triangle \varphi_{1}, \triangle \varphi$ \\
\hline " & 10 & $\measuredangle \varphi_{i 2}$ & $\triangle i_{2}$ \\
\hline " & 14 & $-\triangle \kappa_{11}$ & $\triangle k_{11}$ \\
\hline 104 & $\begin{array}{l}\text { 右の行 下 } \\
\text { 加 } 56 \text { 行目 }\end{array}$ & $\begin{array}{l}\text { す。当所の攝 } \\
\text { 影隹 }\end{array}$ & す。撮影は \\
\hline 105 & 写真 4 & ('64.6.17) & '64, 6. 16) \\
\hline 112 & $\begin{array}{l}\text { 右の行 下 } \\
\text { 加 } 53 \text { 行目 }\end{array}$ & $\begin{array}{l}\text { 写真测量専攻 } \\
\text { 者だけでなく }\end{array}$ & $\begin{array}{l}\text { 写真測量専政者 } \\
\text { でなく }\end{array}$ \\
\hline 113 & 䘚 倩考 & $\begin{array}{l}\text { 防災センター } \\
\text { 撮影 }\end{array}$ & \\
\hline
\end{tabular}
測” 写真测量VI-2，1965，P58-64

\begin{tabular}{|c|c|c|c|}
\hline ペーシ & 行 & 正 & 誤 \\
\hline & & 防鍒庁機撮影 & 防䇥庁機撮影 \\
\hline & & （民間機撮影） & 民間閵撮影 \\
\hline 114 & 右 3 行目 & 会講演概票 & 会請演概專 \\
\hline 136 & 表題英文 & Limitations & Limitation \\
\hline 139 & 左 & 数 $\mathrm{m}$ 以下 & 数以下 \\
\hline
\end{tabular}

\section{正 誤 表}

表紙および中表紙

地質調查 $\rightarrow$ 地震災害調査（表紙） 地質災害調查 $\rightarrow$ 地震災害調查（中衣紙） Limitation $\rightarrow$ Lemitations (英文 Contents 中) in uses $\rightarrow$ in Uses 